NBER WORKING PAPER SERIES

\title{
THE LONG REACH OF CHILDHOOD HEALTH AND CIRCUMSTANCE: EVIDENCE FROM THE WHITEHALL II STUDY
}

\author{
Anne Case \\ Christina Paxson \\ Working Paper 15640 \\ http://www.nber.org/papers/w15640
NATIONAL BUREAU OF ECONOMIC RESEARCH
1050 Massachusetts Avenue
Cambridge, MA 02138
January 2010

This paper has been written for Professor Angus Deaton's festschrift, celebrating his presidency of the American Economic Association. We thank Dr. Aida Sanchez and the Whitehall II team for help accessing the Whitehall II data and Kimberly Bryan for expert research assistance. We thank all participating men and women in the Whitehall II Study; all participating Civil Service departments and their welfare, personnel, and establishment officers; the Occupational Health and Safety Agency; and the Council of Civil Service Unions. The Whitehall II Study team comprises research scientists, statisticians, study coordinators, nurses, data managers, administrative assistants and data entry staff, who make the study possible. Continuing data collection on this study is funded by the Medical Research Council, the National Institute on Aging (AG13196), National Heart Lung and Blood Institute (HL36310) and the British Heart Foundation. We gratefully acknowledge funding from the National Institutes of Health under the Demography of Aging Center grant P30 AG024361. The views expressed herein are those of the authors and do not necessarily reflect the views of the National Bureau of Economic Research.

NBER working papers are circulated for discussion and comment purposes. They have not been peerreviewed or been subject to the review by the NBER Board of Directors that accompanies official NBER publications.

(C) 2010 by Anne Case and Christina Paxson. All rights reserved. Short sections of text, not to exceed two paragraphs, may be quoted without explicit permission provided that full credit, including $\odot$ notice, is given to the source. 
The Long Reach of Childhood Health and Circumstance: Evidence from the Whitehall II Study Anne Case and Christina Paxson

NBER Working Paper No. 15640

January 2010

JEL No. I12,J24,J45

\begin{abstract}
$\underline{\text { ABSTRACT }}$
We use data from the Whitehall II study to examine the potential role played by early-life health and circumstances in determining health and employment status in middle and older ages. The population from which the Whitehall II cohort was drawn consisted almost exclusively of white collar civil servants. We demonstrate that estimates of the impact of early-life conditions based on the Whitehall II cohort provide a lower bound on the effect of early-life circumstances on adult health and economic status for the population as a whole. That said, using the Whitehall II cohort data, we find early life circumstances are all predictive of entry grade and promotion to higher grade in Whitehall. Even with controls for entry grade or current grade, we find that childhood circumstances predict cohort members' current health status. Using fixed effect and first-difference models of self-assessed health status and civil service employment grade, we find no evidence of civil service grade affecting future self-assessed health. However, we find self-assessed health has a significant effect on future civil service grade.
\end{abstract}

\author{
Anne Case \\ 367 Wallace Hall \\ Princeton University \\ Princeton, NJ 08544 \\ and NBER \\ accase@princeton.edu \\ Christina Paxson \\ 424 Robertson Hall \\ Princeton University \\ Princeton, NJ 08544-1022 \\ and NBER \\ cpaxson@princeton.edu
}


That early-life health and environment can have life-long effects on cognitive function, health and wellbeing has been documented by researchers from many disciplines, using data from many countries collected over the last century. In a series of papers, David Barker and colleagues underscore the importance of nutrition in utero for health at older ages, reporting that early-life deprivation is associated with the onset of a number of chronic conditions in late-middle age, including coronary heart disease and diabetes. ${ }^{1}$ They argue that different physical systems and organs may not be able to fully recover from lack of adequate nutrition at critical periods in fetal life and infancy. Exposure to disease in utero and childhood has also been shown to be associated with morbidity and mortality in adulthood (Almond 2006).

Recent research has also highlighted the impact of infant and childhood health on cognitive function, and its consequent impact on occupation and earnings in adulthood. ${ }^{2}$ In work related to our analysis here, Case and Paxson (2008a) document that, in the UK, every inch of height is associated on average with a 1.5 to 2 percent increase in earnings for both men and women, and that this labor market height premium can be explained by the higher cognitive test scores taller adults attained as children. Case and Paxson hypothesize that early life environment - nutrition and health in utero and childhood - affects children's ability to reach both their physical (height) potential and their cognitive potential.

Height, as a marker for health and nutrition in childhood, has been shown to be highly correlated with many outcomes of interest, including later-life cognitive function, health, and depression in the US Health and Retirement Study (Case and Paxson, 2008b); earnings among

\footnotetext{
${ }^{1}$ Reviews of the growing literature on the fetal origins hypothesis are presented in Rasmussen (2001), McMillen and Robinson (2005), and Case and Paxson (2006). Barker (2004) and Black et al. (2007) provide recent studies.

${ }^{2}$ Currie (2009) provides a thorough and thoughtful review.
} 
adults of all ages in the British Household Panel Survey (Case, Paxson and Islam, 2009); and reports of life satisfaction and wellbeing in the US Gallup-Healthways Well-Being Index (Deaton and Arora, 2009).

Some social epidemiologists, while recognizing that early-life health and circumstance may play a role in later-life outcomes, argue that their effects are dwarfed by the impact of adult socioeconomic status on adult health. In a series of influential papers, Michael Marmot and colleagues use longitudinal data collected on a cohort of British civil servants to argue that the impact of social position on changes in health status (the social causation of health) is more important, measured using a number of metrics, than is the impact of health on social position (the health selection hypothesis). (See, for example, discussion in Chandola et al. 2003.) In their analysis of the relative importance of childhood and adult circumstance in predicting cardiovascular disease among civil servants, the Whitehall II team concludes that "whatever the salient features of the adult socioeconomic environment may be, it seems they are equally or more important than circumstances in childhood" in determining cardiovascular risk in British civil servants (Brunner et al. 1999, page 762). Early life is important, these researchers argue, because "childhood circumstances determine adult circumstances and these, in turn, affect disease risk" (Marmot et al. 2001, p. 305).

For many analyses, the Whitehall II Study of British civil servants is well designed. All individuals in the study work for the same employer; they all have access to Britain's National Health Service; and, at the beginning of the study period, they were all employed in London. Marmot and colleagues appeal to the relative homogeneity of their sample to suggest that differences in health outcomes between civil servants cannot be due to differences in access to 
(or quality of) medical care. Instead, they argue, differences in health outcomes between civil servants of higher and lower rank are due primarily to working conditions: seniority in the employment hierarchy predicts longer life, and "high demands and low control at work" predict poor health. ${ }^{3}$ The contribution of the Whitehall II study in documenting the links between adult health status and social status has been large indeed.

In this paper, using data from the Whitehall II study, we concentrate on the potential role played by early-life health and socioeconomic status as determinants of cohort members' health and employment status at Whitehall. We find that, because the population from which this cohort was drawn consisted almost exclusively of white collar civil servants, ${ }^{4}$ the Whitehall II sample is not well suited for quantifying the importance of childhood conditions for the population as a whole. Children from poor backgrounds who find white collar positions in Whitehall are different in many dimensions from other poor children, and these differences lead to a systematic underestimate of the impact of early-life health and circumstances on later-life health and social status.

That said, we find parents' socioeconomic status, cohort members' heights, and reports of their childhood health are all predictive of entry grade and promotion to higher grade in Whitehall. Even with controls for entry grade or current grade we find that cohort members' educational qualifications, their economic and health status as children, mother's education and care-giving, and parents' illness predict health status in middle age and older age. Given that the Whitehall II sample is composed of individuals who were selected into white collar jobs at

\footnotetext{
${ }^{3}$ Findings from the Whitehall II study are available at http://www.ucl.ac.uk/whitehallII/findings/index.htm.

${ }^{4}$ Virtanen et al. (2009) note that "participants in the Whitehall II study are almost exclusively white-collar civil servants" (page 597). Similarly, Singh-Manoux et al. (2004) refer to the Whitehall II cohort as "white collar employees" (page 1073).
} 
Whitehall, we shall show that our estimates provide a lower bound on the impact of early-life health and circumstances on later life health and socioeconomic status for the population as a whole.

Entry grade and current occupational grade at Whitehall are significantly related to selfassessed health in later years of the Study. However, their significance is eliminated by the addition of controls for members' future occupational grades, suggesting that occupational grade may be more of a marker of poorer health than a cause of poorer health. We examine this further by estimating fixed effect models and first-difference models of health status and occupational grade, where we quantify the extent to which change in health status predicts change in civil service grade, and the extent to which change in civil service grade predicts change in health status. We find no evidence of civil service grade affecting future self-assessed health. In contrast, we find robust evidence of self-assessed health affecting future civil service grade.

We begin with an introduction to the Whitehall II data and a comparison of the Whitehall II cohort to two nationally representative British birth cohorts - the National Child Development Study of 1958 (NCDS) and the British Cohort Study of 1970 (BCS). Section 3 presents estimates of the effect of family background and own-health in childhood on placement at Whitehall, and promotion to higher grades. Section 4 investigates the impact of civil service grade and family background on self-assessed health in later phases of Whitehall II, before turning to fixed effect and first difference estimates of the impact of civil service grade on self-assessed health, and the impact of health on civil service grade.

\section{The Whitehall II Study}


Since its inception in 1985, the Whitehall II Study has followed a cohort of British civil servants, 10308 men and women who, at the beginning of the study, were aged 35 to 55 and employed in 20 London-based white collar civil service departments. The Study currently allows researchers to request data from the first six waves (phases) of data collection on health, mental health, working conditions, and health-related behaviors. Phases 1 (1985-88), 3 (1991-94) and 5 (199799) had both a self-administered questionnaire and a medical examination, and phases 2 (198990), 4 (1995-96) and 6 (2001) had mail-in questionnaires. At different phases, cohort members were also asked retrospective questions about their childhoods. (An introduction to these data, and a link to a comprehensive list of Whitehall II publications, is available at http://www.ucl.ac.uk/whitehallII. A description of the variables we use, and the phases from which they are drawn, is presented in Appendix Table 1.)

Summary statistics about this cohort are presented in Table 1, together with information about the two birth cohorts we will use in comparison. The NCDS has followed all children born in England, Scotland and Wales in the week of March 3, 1958 from birth through to middle-age. In a similar fashion, the BCS has been following all individuals living in Great Britain born in the week of April 5, 1970.

Comparison between the Whitehall II cohort and the British birth cohorts is complicated by the fact that employment class in the Whitehall II study is categorized by civil service grade, which is based on salary, while employment class in the birth cohort studies is based on the British Registrar General's occupation classifications. In describing the Whitehall II data, Marmot et al. (1991) write:

On the basis of salary the civil service identifies twelve non-industrial grades which, in order of decreasing salary, comprise seven "unified grades", and senior executive 
officer (SEO), higher executive officer (HEO), executive officer (EO), clerical officer, and clerical assistant. Other professional and technical staff are assigned by the civil service to one of these grades on the basis of salary. For analysis, we have combined unified grades 1-6 into one group and the bottom two clerical grades into another, thus producing six categories. (page 1388)

The Whitehall II team then combines these six categories to create three grades, which they use in most of their analyses: unified grades 1-6 and unified grade 7 define the (highest) "Administrative" grade; the SEO, HEO, and EO define the (second-highest) "Professional and Executive" grade; and the clerical category (which they note includes a small number of officesupport staff) defines the "Clerical/Office Support" grade.

Although these civil service grades do not align with the British Registrar General's occupation scale, it is clear that all but a handful of Whitehall II cohort members would be classified in the Registrar General's top three occupational categories: professional occupations (Class I); managerial and lower professional occupations (Class II); and skilled non-manual occupations (Class III-N). (The example often used to characterize skilled non-manual occupations is "office workers.") In belonging to one of the top three occupational classes, the Whitehall II cohort is different from the population at large. Approximately a third of NCDS and BCS cohort members, for example, report that they are employed in the lower three occupational classes (skilled manual (Class III-M), semi-skilled (Class IV) or unskilled (Class V)).

The distribution of fathers' occupational status in the Whitehall II study is also significantly different from the distributions in the NCDS and BCS, despite the fact that fathers' occupation status is defined the same way across the studies. There has been a shift toward higher status occupations in the UK, which can be seen in the difference in reports of fathers' status between the 1958 and 1970 cohorts. Seventy three percent of fathers were reported to be in 
the lowest three classes in the 1958 cohort - true for 62 percent of the 1970 cohort. However, in the Whitehall cohort, which contains individuals who are older than members of either of these birth cohorts, only 45 percent of fathers were reported in the lowest three classes. As the Whitehall II team notes, although the fathers of cohort members are disproportionately drawn from upper classes, there are still many fathers from lower status occupations (Marmot et al. 2001, page 305). In Section 2 we argue that the absolute number of fathers from lower status occupations is less important than the fact that, in order to be selected for a position at Whitehall, cohort members whose fathers come from lower status occupations must have had higher draws on unobservable variables that influence occupational grade and, potentially, health outcomes. We set out a simple model to demonstrate the effect of selection into Whitehall, and we use the British birth cohorts to investigate the empirical importance of the concentration of the Whitehall II cohort into the top three occupational grades. We present evidence that selection is likely to affect the impact we estimate for father's social class.

\section{Selection into Whitehall and estimation of the impact of childhood conditions}

Selection into white collar positions at Whitehall will depend on an individual's characteristics that are observable to researchers, $C$, and characteristics that make a person a more attractive candidate, but which are not observable to researchers, $u$. Observable characteristics may include measures of family background, such as father's social class, and childhood health. A person is offered a white collar position in the civil service if the probability that the weighted bundle of his or her characteristics $W^{*}$ passes some threshold which, without loss of generality, we set to zero. The probability of employment in a white collar position in Whitehall $(W=1)$ can be written 


$$
\operatorname{pr}(W=1)=\operatorname{pr}\left(W^{*}>0\right)=\operatorname{pr}\left(\alpha^{\prime} C+u>0\right) .
$$

Among individuals employed at Whitehall in white collar jobs, we would expect a negative correlation between observable characteristics $C$ and unobservables $u$. An individual with poor observable characteristics would only land a position at Whitehall if his or her unobservable characteristics were especially strong, strong enough that $\left(\alpha^{\prime} C+u>0\right)$. Other outcomes of interest for an individual, $y$, such as health in adulthood, also depend on an individual's characteristics, a subset of which may be the same variables that helped to determine employment status at Whitehall, $C$, and unobservable characteristics, $\varepsilon$, where $\varepsilon=\theta u+v$ :

$$
y=\gamma^{\prime} X+\beta^{\prime} C+\theta u+v
$$

Correlation in the unobservable variables that determine outcomes in (2) and selection into Whitehall in (1) will lead the ordinary least squares estimates of the impact of $C$ in equation (2) to be inconsistent. Ignoring for ease of exposition the other determinants of individuals' outcomes, we can write the probability limit of our OLS estimate of $\beta$ as

$$
\operatorname{plim} \hat{\beta}=\beta+\operatorname{plim}\left[\frac{C^{\prime} C}{n}\right]^{-1} \operatorname{plim}\left[\frac{C^{\prime} \varepsilon}{n}\right]
$$


Selection into Whitehall induces negative correlation between observables $C$ and unobservables $u$ in the Whitehall II cohort. Positive correlation between unobservables in the selection equation and those for other outcomes of interest would lead the plim $\frac{C^{\prime} \varepsilon}{n}$ to be negative, which would lead in turn to an underestimate of the impact of individual characteristics and family background on outcomes in adulthood.

With data from two nationally representative birth cohorts, we can test whether truncation by occupational status leads to a significantly lower estimate of the impact of family background. Table 2 presents results of OLS regressions in which cohort members' adult height is regressed on indicators for father's occupational status, with the benchmark (omitted category) being that for unskilled work. For the NCDS and BCS cohorts, we control for whether cohort members were white, and male. For the Whitehall II cohort members, we control in addition for age and age squared.

The NCDS and the BCS allow us to run regressions for the whole cohort, and for the cohort restricted to the three highest occupational classes, which are the classes to which almost all of the Whitehall II cohort belong. When we use the full samples, we find that cohort members with fathers whose positions were of higher status are taller in adulthood. Relative to cohort members whose fathers were unskilled in the BCS, members whose fathers were in the highest class are on average 1.8 centimeters taller ( 3.3 centimeters taller in the NCDS).

Turning to the subsample of birth cohort members working in the top three occupational classes, we find that the coefficients for father's occupational grade are smaller than those for the cohort as a whole. This is true for both the BCS and the NCDS. When we restrict the BCS sample to cohort members who report that they work in the top three classes, we find that 
coefficients for father's class become smaller and, for almost all grades, insignificantly different from zero. However, the indicators for father's occupational class continue to be jointly significant, and their joint significance is not much different from that estimated for the Whitehall II sample. For the NCDS, when we use the restricted sample we find that the coefficients on the indicators for fathers' social class are jointly significant and often individually significant. However, they are uniformly smaller than the coefficients obtained with the full sample. For both the BCS and the NCDS, we present chi-square tests of the hypothesis that the coefficients for the indicators of fathers' social class are identical across the full and restricted samples. For the BCS, the hypothesis of equal coefficients cannot be rejected. This is not surprising, given the large standard errors that are obtained using the restricted sample. For the NCDS, the hypothesis that the coefficients are equal can be rejected.

Table 3 presents results for educational attainment in the NCDS birth cohort and the Whitehall II cohort. (Educational categories for the BCS cohort were quite different from the other two surveys, and so we restrict our attention in Table 3 to the NCDS and Whitehall II cohorts.) The NCDS asked cohort members in Stage 5 about their highest educational qualification at age 23. Whitehall II, in phase 5, asked cohort members about their level of academic qualification when they first left full-time education. The answers are scored in a similar fashion in the two surveys. In Whitehall II, these are ranked from "no qualification" (equal to 1), "school certificate" (2), matriculation (3), "O levels" (4) through to "masters degree or higher" (8). We run ordered probit regressions for the two cohorts, since these academic qualifications can be ordered, but the progression from one qualification to the next cannot be easily quantified. 
For the full NCDS cohort, we find a highly significant set of coefficients for father's social class, with a monotonic increase in cohort member's educational attainment by father's occupational status. Moving from the full NCDS cohort to that reporting that their own occupational status is in the top 3 classes dampens the coefficients on father's occupational status, and renders them similar to those observed for the Whitehall II cohort. We reject the hypothesis that the coefficients in the unrestricted and restricted NCDS samples are identical. For the Whitehall II cohort and for the NCDS cohort under the restriction of own-occupation being in one of the top three grades, father's occupational status remains a strong predictor of educational qualification.

To provide a sense of whether restricting analysis to the top three occupational classes makes a significant difference to results measuring the impact of father's occupational status, we run regressions of height, self-assessed health, and educational qualifications on a linear measure of father's occupational status, with higher status occupations given a higher number $(6=$ father was of professional status, $1=$ father was an unskilled laborer). The top panel of Table 4 presents results for the BCS and NCDS samples as a whole, and tests whether father's status has a significantly different effect for these cohorts than it does for the Whitehall II cohort. Height in adulthood, and educational qualification are as discussed above. Self-assessed health in the Whitehall II study was asked using a five point scale (excellent, very good, good, fair and poor), while the birth cohort studies used four point scales (excellent, good, fair and poor). For Whitehall II, we combine "excellent" and "very good" and compare reports of health between the highest category and reports of "good, fair, or poor" health using an indicator variable. 
Consistent with the estimates presented in Tables 2 and 3 we find, for all three outcomes, that cohort members whose fathers were in higher status occupations report significantly better outcomes: cohort members whose fathers were of higher status are taller, they report better health, and their educational qualifications are higher.

The panels of Table 4 allow us to test whether the Whitehall II estimates are different from those of the NCDS and the BCS. For all three outcomes, we find in panel 1 that father's social class has a significantly larger effect in the BCS and the NCDS than is true for the Whitehall II cohort. However, when we restrict the sample to BCS and NCDS cohort members in professional, managerial and skilled,non-manual classes, we find no significant difference between the impact of father's status in the birth cohorts and in Whitehall II. We conclude from this that the selection into white collar positions in Whitehall diminishes the estimated impact of family background.

The problem identified here - that analyses based on a select group may not provide unbiased information for the population as a whole - affects many more analyses than just those based on the Whitehall data. For example, Davey Smith et al. (1998) use longitudinal data on a sample of adults originally selected from 27 workplaces in the west of Scotland to examine the relative importance of education and adult occupational (social) class as determinants of mortality. To investigate this issue, they stratify their data on occupational status, and measure the strength of the relationships between education and mortality. They also stratify their data on education, and measure the strength of the relationships between occupational status and mortality. They observe "the ... association between social class and all cause mortality remains strong within education strata, whereas within social class strata the relation between education 
and mortality is less clear" (page 153). From this they conclude that although both education and social class are important determinants of morbidity and mortality, "occupational class is more strongly associated with overall ... mortality than is the education measure" (page 158). In turn, this evidence is cited by Singh-Manoux et al. (2004) that "research clearly shows adult measures of SEP [socioeconomic position] to be more powerful predictors of health than SEP measures from earlier in the life course" (page 1073).

For reasons outlined above, however, because this analysis does not account for selection into occupational status, the estimated associations between education and health within social strata will be biased toward zero and the estimated associations between occupational status and health within education strata will be biased away from zero. That is, for school leavers at age 16 (say), those who are stronger on dimensions not measured in our data will be selected into higher classes and will be healthier, so that an analysis of the association between occupational class and health within an educational stratum will overestimate the association between class and health. Within an occupational class, for those with lower educational attainment to reach any given occupational stratum, they must have been strong in dimensions that are not measured in our data. This will lead to an underestimate of the association between education and health.

Bearing this in mind, we turn next to examine the association between childhood background and economic wellbeing in adulthood, measured using initial occupational grade and promotion at Whitehall II.

\section{The economic consequences of childhood health and circumstance}


We begin by investigating the extent to which family background is associated with cohort members' first occupational grade in Whitehall, and promotion to a higher grade over time. Several elements of family background may be associated with initial grade assignment, including father's social class; the cohort member's report on whether his or her family owned a car when the member was less than 16; reports on whether the cohort member spent 4 or more weeks in the hospital when less than 16; and the member's adult height. Together with father's social class, car ownership gives us a window onto the cohort member's socioeconomic status in childhood. Reports on hospitalization tell us something about health in childhood, as does the member's height. ${ }^{5}$

That height is associated with cohort members' initial placement at Whitehall can be seen in Figure 1, which presents non-parametric regression results of initial grade (1=clerical, $2=$ professional/executive, $3=$ administrative) regressed on height, separately for men and women. Women are more likely to start in a lower grade than are men, but throughout the distribution of women's heights, we find a linear positive relationship between height and initial placement. For men, the relationship is positive up to heights of approximately 180 centimeters (the $75^{\text {th }}$ percentile of height for men). The slopes for women and men (through 180 centimeters for men) are remarkably similar. We examine this association further in Table 5.

Columns 1 and 3 of Table 5 present OLS regression results on the association between family and cohort member's characteristics and initial placement at Whitehall. Column 1 reports results without educational qualifications included as controls. Results in column 3 include indicators of academic qualifications. Father's occupational status is strongly correlated with a

\footnotetext{
${ }^{5}$ Height was measured in phases 1, 3 and 5 . We use the mean of the height measures recorded for each member.
} 
cohort member's starting grade. Members whose fathers were in the highest occupational class were on average almost half an occupational grade $(0.425)$ higher at entry than were cohort members whose fathers were unskilled laborers (the omitted occupational category). There is a monotonic relationship between father's occupational class and starting grade. Jointly, these variables are significant $(F$-test $=27.4, p$-value $=0.000)$. Coming from a family that owned a car also predicts higher entry grade, while reporting that one spent more than 4 weeks in the hospital as a child predicts lower entry grade. These two background variables are also jointly significant $(F$-test $=14.6, p$-value $=0.000)$.

Much of the association between family background and initial placement appears to work through educational attainment. Column 3 of Table 5 adds a complete set of indicators for highest academic qualification when first leaving full-time education. Jointly, these variables are highly significant in the initial placement regression $(F$-test $=150.7, p$-value $=0.000)$, and their inclusion reduces the estimated association between entry grade and father's occupational class, and between entry grade and other childhood variables. We know from Table 3 that father's occupational class is highly correlated with a cohort member's educational qualification. Spending time in the hospital as a child is negatively associated with educational attainment, while car ownership is positively associated with educational qualification. Even with controls for educational attainment, height continues to predict grade at entry.

We present the regression coefficients on our education qualification variables in Figure 2. Additional qualifications strongly predict higher entry grade into Whitehall, with those entering with a Bachelor's degree on average reporting more than 0.6 grades higher than those 
entering with no academic qualifications (the benchmark group), and those with a Master's degree or $\mathrm{PhD}$ reporting more than 0.8 grades higher.

The second set of regressions in Table 5 investigates the relationship between reporting promotion to a higher grade at Whitehall, and family and individual characteristics. We define promotion as a member reporting a higher occupational grade the last time this member is observed than the grade he or she reported as their starting grade. Each cohort member appears once in these regressions, even if he or she had more than one promotion. Column 2 reports results without educational qualifications added as controls, and column 4 with indicators of academic qualifications included. We restrict the sample here to individuals who entered Whitehall at a grade lower than the top grade (it is rare for people to be demoted at Whitehall), and we control for starting grade (allowing a level difference in the probability of moving from a 'clerical' to a 'professional' grade from that of moving from a 'professional' to an 'administrative' grade) ${ }^{6}$

We also include a control for self-assessed health in phase 1 of the Study. Specifically, we include an indicator that the individual reports they were "moderately" or "very" satisfied with their health at phase 1 (true for two-thirds of respondents). These respondents are significantly more likely to report promotion. Three variables that are associated with health self-assessment of health at the beginning of the Study, an individual's height, and his or her report of having spent time in the hospital as a child - are all significantly associated with promotion at Whitehall. This is true with or without controls for educational attainment.

\footnotetext{
${ }^{6}$ Results that do not include controls for entry grade are very similar to those presented in columns 2 and 4.
} 
Figure 3 examines whether height matters for promotion throughout the distribution, or is only important for especially short or especially tall cohort members. We find for both men and women, throughout the distribution of heights, an additional centimeter of height is associated with an increased probability of promotion.

Father's occupational status is highly associated with grade promotion. This effect appears to work through cohort members' educational attainment. The impact of education on the probability of promotion is presented in Figure 4, where regression coefficients are presented for educational qualifications relative to no academic qualification (the benchmark group). Members with a Bachelor's degree are fifty percent more likely to report a promotion than are those who lack educational qualifications. Those with a Master's or $\mathrm{PhD}$ are nearly sixty percent more likely to report promotion.

Results in Table 5 demonstrate that, even in this sample of white collar workers, childhood socioeconomic status, measured using father's occupational status, and family car ownership during childhood, are strongly associated with entry grade and with promotion. Their effects appear to work through the impact that they have on cohort members' education, which is strongly associated with both initial grade and promotion. Results in Table 5 also demonstrate that childhood health, as measured using height and reports of hospitalization before age 16, also affects entry grade and promotion in Whitehall. Part of the impact of childhood health on entry grade appears to work through education, However, childhood health appears to have effects on promotion independent of educational attainment, and even controlling for satisfaction with health at phase 1. 
Childhood health and circumstances not only put Whitehall white collar workers at different grades initially, but also lead to a widening in earnings gaps over time: those who were healthy in childhood, and those from higher SES backgrounds are significantly more likely to be promoted. We turn next to see whether the long reach of childhood extends to health in adulthood, before turning to the timing of changes in health and changes in adult socioeconomic status, as measured by employment grade.

\section{Childhood circumstances and adult health}

Cohort members were asked to assess their health in phase 3 (1991-1994), phase 4 (1995-1996), phase 5 (1997-1999) and phase 6 (2001). Specifically, they were to answer "in general would you say your health is ... excellent, very good, good, fair or poor." A poor self-report of health is a powerful predictor of mortality, even when controlling for physician assessed health status and health-related behaviors. Poor self-reports of health are also a significant predictor of future changes in functioning among the elderly. ${ }^{7}$ We code self-assessed health so that a higher number corresponds to better self-reported health ( $1=$ poor, $5=$ excellent). In phase 3,12 percent of respondents reported their health was 'excellent;' 36 percent 'very good;' 40 percent 'good;' 10 percent 'fair;' and 1 percent 'poor.' We run ordered probit regressions to examine the associations between childhood circumstances, economic status in adulthood, and self-assessed health. The results presented are robust to estimating the models using ordinary least squares, using an indicator that health is reported to be 'excellent' or 'very good' as the dependent variable.

\footnotetext{
${ }^{7}$ Idler and Kasl (1995) and Bowling (2005) provide extensive references on studies that have employed self reported health status.
} 
Table 6 presents results on the correlates of self-assessed health, including measures of occupational status at different points in time, cohort members' heights, an indicator for whether the member reports having spent more than 4 weeks in the hospital as a child; and an indicator for whether the member reports the family owned a car when he or she was less than 16 . Case and Paxson (2001) find that mother's characteristics are associated with health-related behaviors, and for this reason we include controls for members' reports that their mothers gave them 'a great deal of time' when growing up, and controls for mothers' school leaving age and that age squared. We include members' reports that a parent suffered from high blood pressure, stroke, angina, and diabetes. We continue to include a complete set of indicators for highest academic qualification when first leaving full-time education, and members' ethnicity, sex, age and age squared. For ease of exposition, Table 6 displays only some of the ordered probit coefficients, and at the bottom of the table we show chi-square test statistics for the joint significance of subsets of coefficients.

Table 6 shows that self-assessed health is strongly related to occupational status at Whitehall. Column 1 shows that cohort members' initial grades are significantly related to their current health. In addition, even with a control for starting grade, conditions of childhood are significantly associated with self-assessed health. Children who report having spent time in the hospital as a child are 7 percentage points less likely to report 'excellent' or 'very good' health. Mother's variables, parental illness, and academic qualifications are all strongly associated with cohort members' health. ${ }^{8}$

\footnotetext{
${ }^{8}$ Similar results on the importance of education are presented by Smith (2007), who finds education critical to future health outcomes in the Panel Study of Income Dynamics.
} 
To examine whether childhood circumstances may act through their effects on promotion in Whitehall, we include current grade at Whitehall in our ordered probit regression in column 2. Current grade is strongly related to current health status, and its inclusion eliminates the association between starting grade and health status. Moving up one grade is associated with a 7 percentage point increase in the probability of reporting excellent or very good health. However, its inclusion does little to dampen the impact of childhood circumstances on current health: coefficients change little, and the subsets continue to be highly jointly significant.

These results lead us back to the stubborn question of whether occupational grade is high because health is good, or whether health is good because occupational grade is high. Results in Table 5 suggest that promotion is related to health: promotion is predicted by better health in phase 1; by not reporting childhood hospitalizations; and by adult height. To get some purchase on this question, we add to our probit regressions measures of future occupational status. Specifically, column 3 adds occupational grade at the next phase of the Study. Future grade is highly and significantly correlated with current health, and its inclusion eliminates the association between current grade and health status. These results hold whether we include grade at the next phase of Whitehall (column 3), or the phase after that (column 4). It is difficult to make a case for future grade having a direct effect on current health. One might anticipate not being eligible for promotion, and this may lead to poorer health today, but it seems unlikely that one will anticipate equally well promotion in the next 3 year (occupational grade next phase) and in the next 6 years (occupational grade two phases into the future). An alternative explanation is that those in better health today are more likely to be promoted between the phases of the study. 
We pursue this by estimating fixed effect regression models for health status $(\mathrm{H})$ and civil service grade $(\mathrm{G})$ for cohort member $i$ observed at time $t$ of the form:

$$
H_{i t}=\gamma_{1}^{\prime} G_{i, t-1}+\gamma_{2}^{\prime} G_{i, t-2}+\beta^{\prime} a_{i t}+\alpha_{i}+\varepsilon_{i, t}
$$

and

$$
G_{i t}=\theta_{1}{ }^{\prime} H_{i, t-1}+\theta_{2}{ }^{\prime} H_{i, t-2}+\lambda^{\prime} a_{i t}+\delta_{i}+u_{i, t} .
$$

Equation (4) regresses an indicator that the cohort member currently reports 'excellent' or 'very good' health on lags of civil service grade, age $a$ at time $t$, and individual fixed effects, while equation (5) regresses current civil service grade on lags in health status (indicators of reporting 'excellent' or 'very good' health), age at time $t$, and individual fixed effects. Fixed effects will absorb aspects about individuals' backgrounds that may determine both health status and economic status in adulthood, such as parents' educations, occupations and health status; health and economic status in childhood; and educational attainment.

We present fixed effect results for health status in the first two columns of Table 7, and those for civil service grade in columns 4 and 5 . We find no evidence that lagged civil service grade affects health status. The coefficients on lagged civil service grade are small and insignificantly different from zero. In contrast, cohort members who report 'excellent' or 'very good' health are significantly more likely to be promoted.

Fixed effect estimation requires the stringent assumption that all explanatory variables are strictly exogenous, an assumption that is unlikely to be true for our model of health and occupational status. For this reason, we also estimate equations (4) and (5) using first difference models of the form:

$$
H_{i t}-H_{i, t-1}=\gamma_{2}^{\prime}\left(G_{i, t-2}-G_{i, t-3}\right)+\beta^{\prime}\left(a_{i t}-a_{i, t-1}\right)+\left(\varepsilon_{i, t}-\varepsilon_{i, t-1}\right)
$$


and

$$
G_{i t}-G_{i, t-1}=\theta_{2}^{\prime}\left(H_{i, t-2}-H_{i, t-3}\right)+\lambda^{\prime}\left(a_{i t}-a_{i, t-1}\right)+\left(u_{i, t}-u_{i, t-1}\right)
$$

Here, we rely only on the second lag of employment grade (for equation 6) and health status (for equation 7), to minimize the odds that these right side variables are correlated with the firstdifferenced error term. Our first-difference results are very similar to our fixed effect estimates. We find no effect of civil service grade on future health. However, consistent with the results presented in Tables 5 and 6, we find a significant effect of health on future civil service grade.

\section{Conclusions}

The results in this paper highlight three important issues for research on health and economic status over the life-course. The first finding is cautionary: samples of individuals who have been selected into certain occupational groups are not adequate to draw inference about the effects of childhood circumstance on adult outcomes for the population as a whole. Whitehall II is a remarkable study that has generated important insights about the evolution of health in adulthood. However, it is important to keep in mind that the Study is not representative of the population. Instead, it consists of people who entered white collar jobs in the British civil service in London. Our results from the NCDS and BCS indicate that, as theory predicts, the estimated effects of childhood factors on adult health and economic outcomes are biased toward zero when samples are restricted to include only individuals from higher-status occupations. We find that results based on selected samples of higher-occupation individuals from the NCDS and BCS are very similar to those based on the Whitehall II data. Our estimates suggest that the effects of 
childhood circumstances on adult outcomes for the population at large are larger than those indicated by Whitehall II results.

Our second major finding is that, despite the downward biases that are likely to result from selection into Whitehall II, we still find evidence that health in childhood influences occupational status in adulthood. Adults who had better childhood health—as measured by adult height and hospitalizations in childhood—start at higher grades in the civil service, and are promoted to higher grades after they enter the civil service. The association between height and occupational status in adulthood is robust to controls for education, implying that childhood health does not operate solely through its effects on educational attainment.

Finally, we present evidence that changes in self-assessed health are related to future changes in employment grade, and that changes in employment grade are not related to changes in future health. These findings are consistent with the hypothesis that the strong correlation between health and employment grade reflects the effects of health on success in the workplace. It should be noted that this finding, although striking, is based on only one measure of healthself-assessed health status. Although self-assessed health status is highly predictive of future mortality and is strongly correlated with a range of health conditions, different results may be obtained using different measures of health. In the future, it would be useful to examine whether similar results are obtained when different measures of health, such as cardiovascular disease or depression, are used in place of self-assessed health. 


\section{References}

Almond, Douglas (2006). "Is the 1918 influenza pandemic over? Long-term effects of in utero influenza exposure in the post-1940 U.S. population." Journal of Political Economy, vol. 114(4), pp. 672-712.

Barker, D.J.P. 2004. “The Developmental Origins of Well-being.” Philosophical Transactions of the Royal Society B, vol. 359(1449), pp. 1359-66.

Bowling, Ann (2005). "Just one question: if it works why ask several?" Journal of Epidemiology and Community Health, vol. 59(5), pp.342-345.

Black, Sandra E., Paul J. Devereux, and Salvanes, Kjell G. (2007). "From the cradle to the labor market? The effect of birth weight on adult outcomes." Quarterly Journal of Economics, vol. 122(1), pp. 409-439.

Brunner, Eric, Shipley, Blane, Davey Smith, George and Marmot, Michael. 1999. "When does cardiovascular risk start? Past and present socioeconomic circumstances and risk factors in adulthood," Journal of Epidemiology and Community Health 53, 757-64

Case, Anne and Paxson, Christina (2006). "Children's health and social mobility." The Future of Children, vol. 16 (2), pp. 151-73.

Case, Anne and Paxson, Christina (2001). "Mothers and Others: Who Invests in Children's Health?” Journal of Health Economics, vol. 20, pp. 301-328.

Case, Anne and Paxson, Christina (2008a). "Stature and status: height, health and labor market outcomes.” Journal of Political Economy, vol. 116(3), pp. 499-532.

Case, Anne and Paxson, Christina (2008b). "Height, health and cognitive function at older ages." American Economic Review Papers and Proceedings, vol. 98 (2), pp. 463-7.

Case, Anne, Paxson, Christina, and Islam, Mahnaz (2009). "Making sense of the labor market height premium: evidence from the British Household Panel Survey." Economic Letters, vol. 102, pp. 174-6.

Chandola, Tarani, Bartley, Mel, Sacker, Amanda, Jenkinson, Crispin, and Marmot,Michael (2003). "Health Selection in the Whitehall II Study, UK" Social Science and Medicine, vol. 56(10), pp. 2059-72.

Currie, Janet (2009). "Healthy, wealthy and wise? Socioeconomic status, poor health in childhood and human capital development." Journal of Economic Literature, vol. 47 (1), pp. 87122. 
Davey Smith, George, Hart, Carol, Hole, David, MacKinnon, Pauline, Gillis, Charles, Watt, Graham, Blane, David, and Hawthorne, Victor (1998). "Education and occupation social class: Which is the more important indicator of mortality risk?" Journal of Epidemiology and Community Health, vol. 52(3), pp. 153-60.

Deaton, Angus and Arora, Raksha (2009). "Life at the top: the benefits of height." Economics and Human Biology, vol. 7(2), pp. 133-6.

Idler, Ellen L. and Kasl, Stanislav V. (1995). "Self-Ratings of Health: Do They Also Predict Change in Functional Ability?" Journal of Gerontology: Social Sciences, vol. 508(6), pp. S344S353.

Marmot, M.G., Davey Smith, George, Stansfeld, Stephen, Patel, Chandra, North, Fiona, Head, Jenny, White, Ian, Brunner, Eric, and Feeney, Amanda (1991). "Health inequalities among British civil servants: The Whitehall II study.” Lancet, vol. 337(8754), pp.1387-93.

Marmot, M., Shipley, M., Brunner, M. and Hemingway, M. (2001). "Relative contribution of early life and adult socioeconomic factors to adult morbidity in the Whitehall II study." Journal of Epidemiology and Community Health, vol. 55, pp. 301-7.

McMillen, Caroline and Robinson, Jeffrey S. (2005). "Developmental origins of the metabolic syndrome.” Physiological Reviews, vol. 85, pp. 571-633.

Rasmussen, Kathleen Maher (2001). “The 'Fetal Origins' Hypothesis: challenges and opportunities for maternal and child nutrition.” Annual Review of Nutrition, vol. 21, pp. 73-95.

Singh-Manoux, Archana, Ferrie, Jane E., Chandola, Tarani and Marmot, Michael (2004). "Socioeconomic trajectories across the life course and health outcomes in midlife: Evidence for the accumulation hypothesis?" International Journal of Epidemiology, vol.33, pp. 1072-9.

Smith, James P. (2007). "The impact of socioeconomic status on health over the life-course." Journal of Human Resources, vol. 42 (4): pp. 739-764.

Virtanen, Marianna, Singh-Manoux, Archana, Ferrie, Jane E., Gimeno, David, Marmot, Michael G., Elovainio, Marko, Jokela, Markus, Vahtera, Jussi, and Kivimäki, Mika (2009). "Long working hours and cognitive function." American Journal of Epidemiology, vol. 169(5), pp. 596605. 


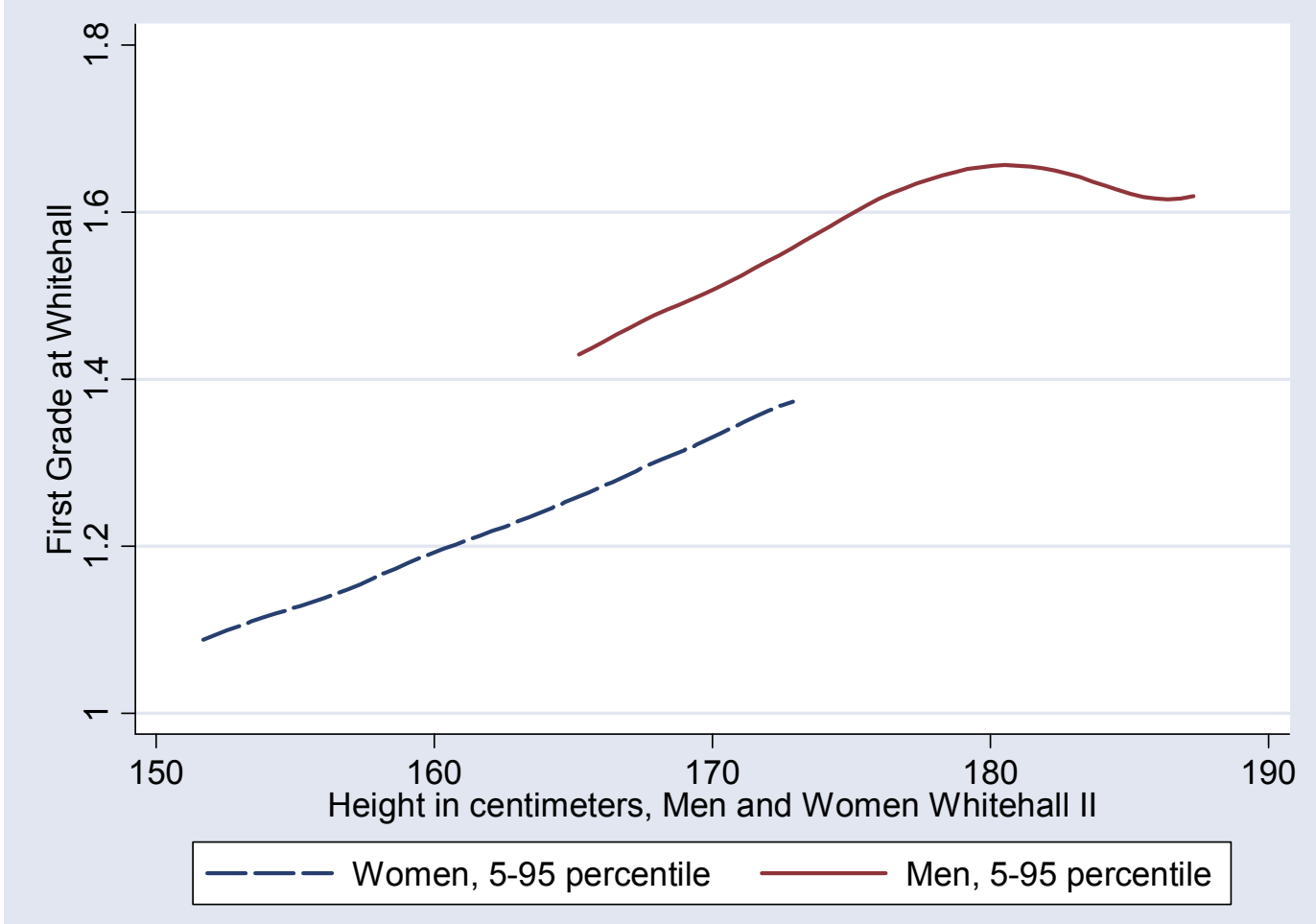

Figure 1. Height and first occupational grade at Whitehall

Grade is measured: (1=Clerical, 2=Professional/Executive, 3=Administrative). 


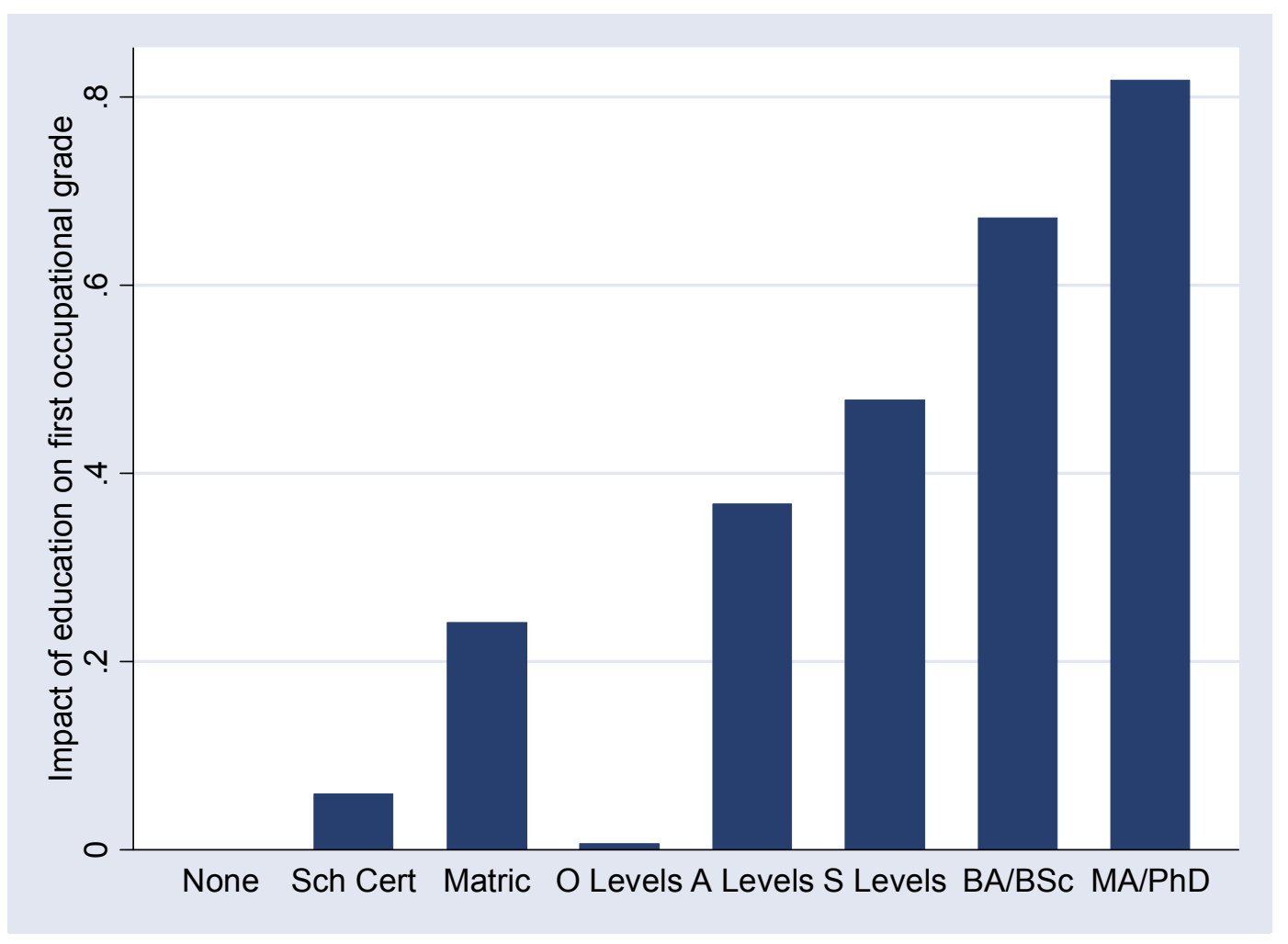

Figure 2. OLS Estimates of the impact of education on occupational grade

Grade is measured: ( $1=$ Clerical, $2=$ Professional/Executive, $3=$ Administrative). These estimates are coefficients on indicators for first academic qualification upon leaving full time schooling, in a regression of first occupation grade at Whitehall regressed on a complete set of indicators for educational qualification, father's social class, an indicator that the cohort member reports his or her family had a car when he/she was less that 16 , an indicator that the cohort member reports being in the hospital for 4 or more weeks when he/she was less than 16, with controls for race, sex, age and age squared. 


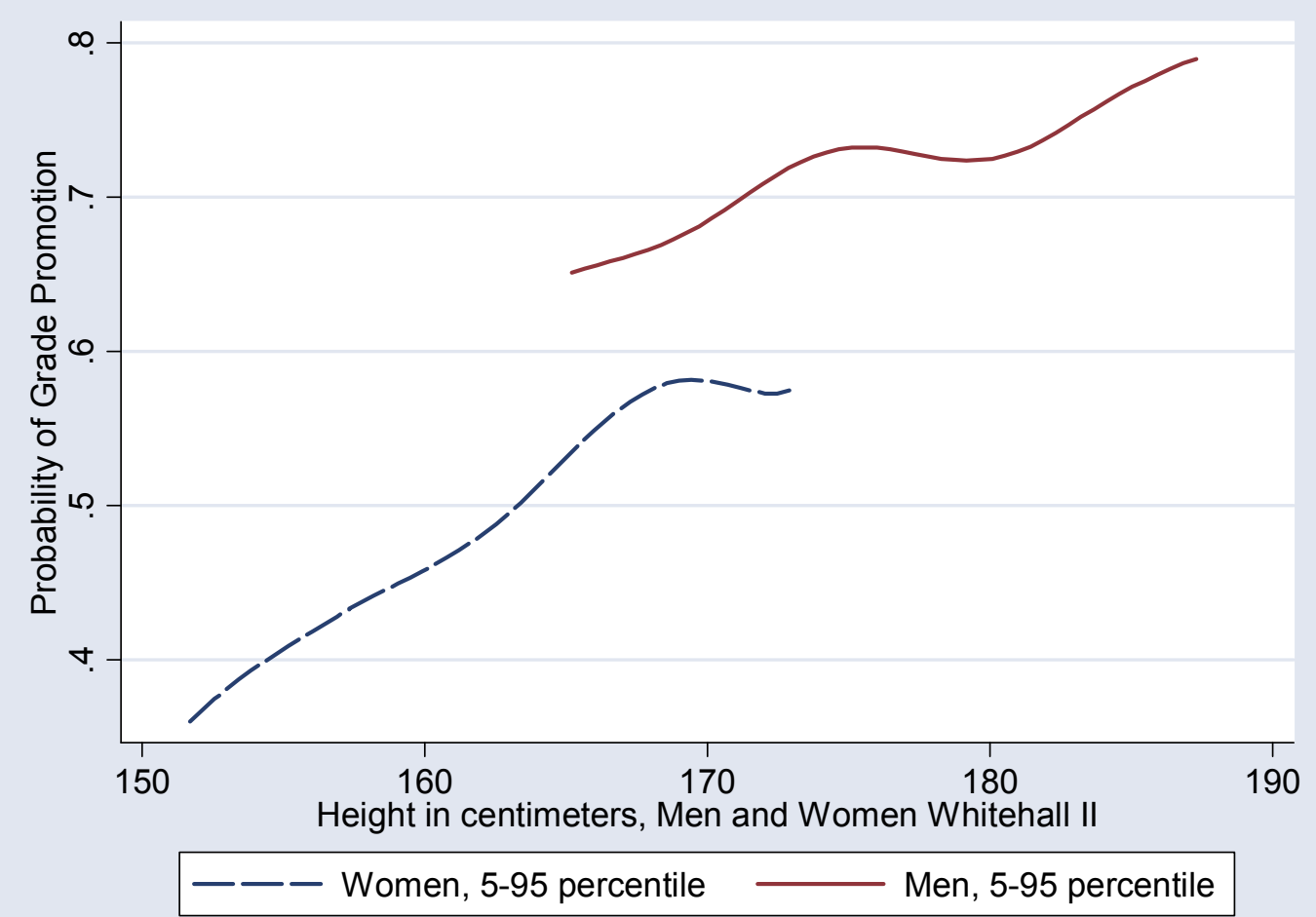

Figure 3. Height and the probability of reporting a grade promotion at Whitehall 


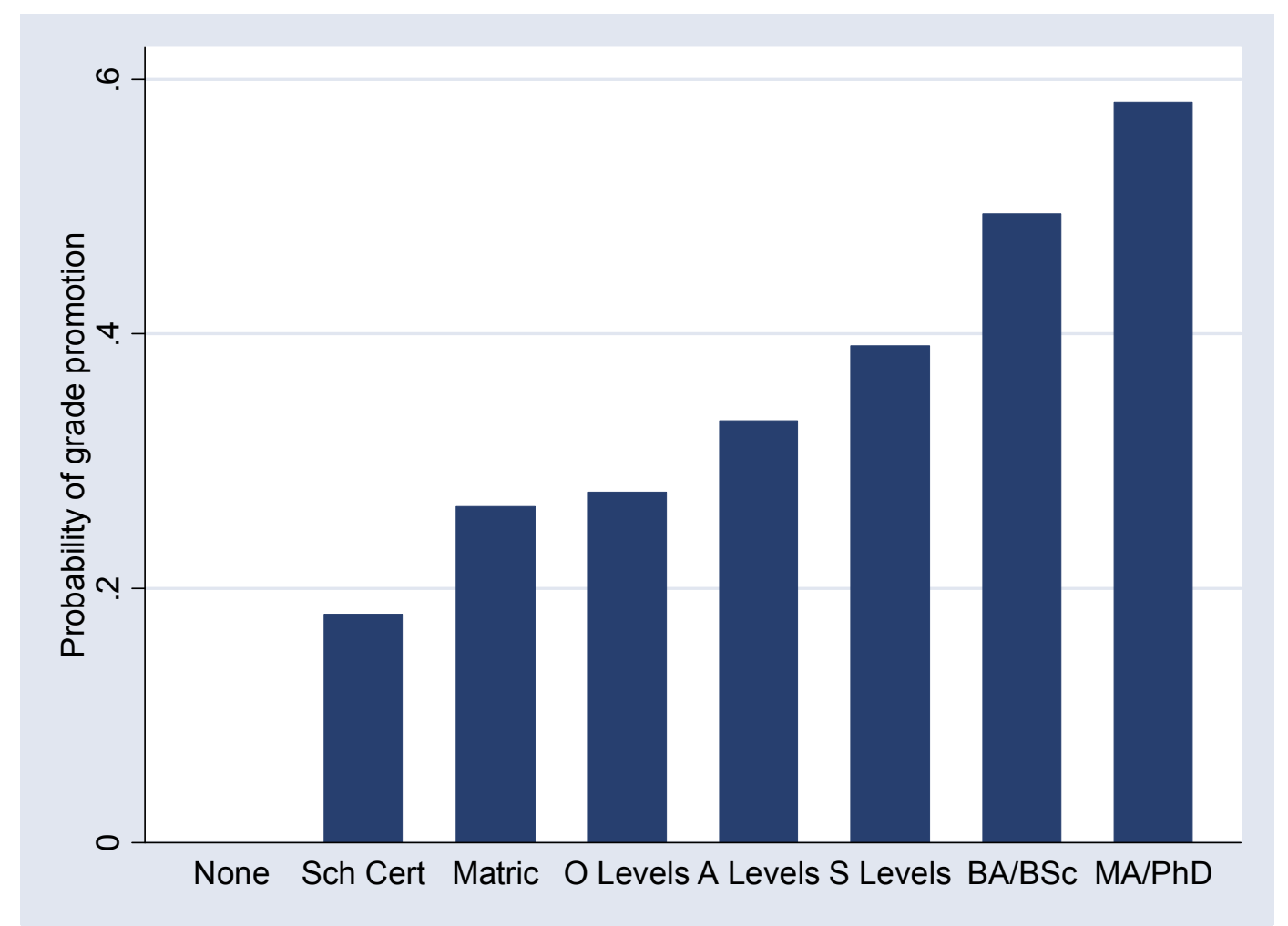

Figure 4. OLS Estimates of the impact of education on promotion to a higher occupational grade

These estimates are coefficients from a regression of promotion to a higher grade at Whitehall between the first and last time each cohort member was observed. The regression includes a complete set of indicators for educational qualification, father's occupational class, an indicator that the cohort member reports his or her family had a car when he/she was less that 16 , an indicator that the cohort member reports being in the hospital for 4 or more weeks when he/she was less than 16, report of being "moderately" or "very" satisfied with their health at phase 1, adult height, initial grade at Whitehall, and controls for race, sex, age and age squared at phase 1. The sample is restricted to those cohort members who initially reported clerical or professional/executive grades. (Those who entered in the top grade cannot be promoted.) 
Table 1. Summary statistics for Whitehall II, BCS and NCDS

\begin{tabular}{|c|c|c|c|}
\hline & Whitehall II & BCS (1970) & NCDS (1958) \\
\hline European/Caucasian & 0.891 & 0.958 & 0.965 \\
\hline Male & 0.669 & 0.520 & 0.517 \\
\hline $\begin{array}{l}\text { Registrar General Occupation } \\
\text { Classification: }\end{array}$ & & age 30 & age 42 \\
\hline Professional & -- & 0.063 & 0.053 \\
\hline Managerial & -- & 0.347 & 0.376 \\
\hline Skilled, non-manual & -- & 0.247 & 0.213 \\
\hline Skilled, manual & -- & 0.207 & 0.202 \\
\hline Semi-skilled & -- & 0.110 & 0.123 \\
\hline Unskilled & -- & 0.028 & 0.033 \\
\hline Civil Service Grade: & Phase 1 (mean age 44) & & \\
\hline Administrative & 0.294 & -- & -- \\
\hline Professional/Executive & 0.480 & -- & -- \\
\hline Clerical/Office Support & 0.227 & -- & -- \\
\hline \multicolumn{4}{|l|}{ Father's social class: } \\
\hline Professional & 0.094 & 0.068 & 0.045 \\
\hline Managerial & 0.305 & 0.229 & 0.130 \\
\hline Skilled, non-manual & 0.155 & 0.086 & 0.097 \\
\hline Skilled, manual & 0.332 & 0.456 & 0.509 \\
\hline Semi-skilled & 0.073 & 0.122 & 0.121 \\
\hline Unskilled & 0.042 & 0.038 & 0.098 \\
\hline Height in $\mathrm{cm}$ (males) & 176.2 & 177.1 & 176.7 \\
\hline Height in $\mathrm{cm}$ (females) & 161.9 & 162.9 & 162.9 \\
\hline $\begin{array}{l}\text { Self-assessed health, reported } \\
\text { at }\end{array}$ & $\begin{array}{c}\text { phases } 3-6 \\
\text { (mean age } 54)\end{array}$ & age 30 & age 42 \\
\hline $\begin{array}{l}\text { Excellent (BCS,NCDS) or } \\
\text { Excellent/Very Good (WII) }\end{array}$ & 0.491 & 0.319 & 0.182 \\
\hline \multicolumn{4}{|l|}{ Childhood conditions: } \\
\hline Spent $4+$ weeks in hospital & 0.133 & & \\
\hline Family owned a car & 0.415 & & \\
\hline $\begin{array}{l}\text { Number observations } \\
\text { (measured at) }\end{array}$ & $\begin{array}{c}10308 \\
\text { (phase 1) }\end{array}$ & $\begin{array}{c}11261 \\
\text { (age 30) }\end{array}$ & $\begin{array}{c}11384 \\
\text { (age } 42 \text { ) }\end{array}$ \\
\hline
\end{tabular}


Table 2. Height in adulthood and father's social class

\begin{tabular}{|c|c|c|c|c|c|}
\hline & \multicolumn{2}{|c|}{$\begin{array}{l}\text { BCS 70: } \\
\text { Height at age } 30 \\
\text { OLS Regression }\end{array}$} & \multicolumn{2}{|c|}{$\begin{array}{l}\text { NCDS 58: } \\
\text { Height at age } 33 \\
\text { OLS Regression }\end{array}$} & \multirow{2}{*}{$\begin{array}{c}\text { Whitehall II } \\
\text { Mean height } \\
\text { OLS Regression } \\
\text { Own grade is } \\
\text { Administrative; } \\
\text { Prof/Exec; } \\
\text { Clerical }\end{array}$} \\
\hline & All & $\begin{array}{l}\text { Own grade is } \\
\text { Prof, Managerial, } \\
\text { Skilled non-manual }\end{array}$ & All & $\begin{array}{l}\text { Own grade is } \\
\text { Prof, } \\
\text { Managerial, } \\
\text { Skilled non- } \\
\text { manual }\end{array}$ & \\
\hline \multicolumn{6}{|l|}{$\begin{array}{l}\text { Indicator: Father's } \\
\text { Class was }\end{array}$} \\
\hline Professional & $\begin{array}{c}1.764 * * * \\
(0.547)\end{array}$ & $\begin{array}{c}0.958 \\
(0.803)\end{array}$ & $\begin{array}{c}3.286^{* * * *} \\
(0.401)\end{array}$ & $\begin{array}{c}3.145 * * * \\
(0.543)\end{array}$ & $\begin{array}{c}2.056 * * * \\
(0.456)\end{array}$ \\
\hline Managerial & $\begin{array}{c}1.806^{* * *} \\
(0.486)\end{array}$ & $\begin{array}{l}1.257^{*} \\
(0.757)\end{array}$ & $\begin{array}{c}2.370 * * * \\
(0.305)\end{array}$ & $\begin{array}{c}1.789 * * * \\
(0.449)\end{array}$ & $\begin{array}{c}1.799 * * * \\
(0.405)\end{array}$ \\
\hline Skilled, non-manual & $\begin{array}{c}1.460 * * * \\
(0.533)\end{array}$ & $\begin{array}{c}0.948 \\
(0.804)\end{array}$ & $\begin{array}{c}1.467 * * * \\
(0.324)\end{array}$ & $\begin{array}{l}1.241 * * * \\
(0.474)\end{array}$ & $\begin{array}{c}1.845 * * * \\
(0.427)\end{array}$ \\
\hline Skilled, manual & $\begin{array}{l}-0.006 \\
(0.472)\end{array}$ & $\begin{array}{l}-0.571 \\
(0.751)\end{array}$ & $\begin{array}{c}1.044 * * * \\
(0.261)\end{array}$ & $\begin{array}{c}1.091 * * * \\
(0.411)\end{array}$ & $\begin{array}{c}1.085 * * * \\
(0.401)\end{array}$ \\
\hline Semi-skilled & $\begin{array}{c}0.127 \\
(0.515)\end{array}$ & $\begin{array}{l}-0.012 \\
(0.812)\end{array}$ & $\begin{array}{c}0.616^{* *} \\
(0.312)\end{array}$ & $\begin{array}{c}0.230 \\
(0.491)\end{array}$ & $\begin{array}{l}0.878^{*} \\
(0.473)\end{array}$ \\
\hline $\begin{array}{l}F \text {-test ( } p \text {-value) } \\
\text { Sig of father classes }\end{array}$ & $\begin{array}{c}21.45 \\
(0.0000)\end{array}$ & $\begin{array}{c}11.39 \\
(0.0000)\end{array}$ & $\begin{array}{c}23.98 \\
(0.0000)\end{array}$ & $\begin{array}{c}10.59 \\
(0.0000)\end{array}$ & $\begin{array}{c}8.27 \\
(0.0000)\end{array}$ \\
\hline $\begin{array}{l}\text { Chi-square test ( } p \text { - } \\
\text { value), equality of } \\
\text { coefficients }\end{array}$ & \multicolumn{2}{|r|}{$\begin{array}{c}6.58 \\
(0.2541)\end{array}$} & \multicolumn{2}{|c|}{$\begin{array}{c}14.03 \\
(0.0154)\end{array}$} & \\
\hline Number obs & 7347 & 4040 & 9256 & 4528 & 6919 \\
\hline
\end{tabular}

Notes. OLS regression coefficients reported, with standard errors presented in parentheses. All regressions include indicators for ethnicity and sex. Whitehall II regressions also include controls for age and age squared at phase 1 . In all regressions, the benchmark for father's social class is unskilled. The chi-square tests for equality of coefficients test the null hypothesis that the coefficients on the father's class indicators are equal across columns 1 and 2 (BCS) and across columns 3 and 4 (NCDS). 
Table 3. Educational Attainment and Father's Social Class

\begin{tabular}{|c|c|c|c|}
\hline & \multicolumn{2}{|c|}{$\begin{array}{c}\text { NCDS } 1958 \text { cohort: } \\
\text { Educational Qualification } \\
\text { Ordered Probit }\end{array}$} & \multirow{2}{*}{$\begin{array}{c}\text { Whitehall II Educationa } \\
\text { Qualification } \\
\text { Ordered Probit } \\
\text { Own grade is } \\
\text { Administrative; } \\
\text { Prof/Executive; Clerica }\end{array}$} \\
\hline & All & $\begin{array}{c}\text { Own grade is } \\
\text { Prof; Managerial; } \\
\text { Skilled non-manual }\end{array}$ & \\
\hline \multicolumn{4}{|l|}{ Indicator: Father's Class was } \\
\hline Professional & $\begin{array}{c}1.649 * * * \\
(0.062)\end{array}$ & $\begin{array}{c}1.363 * * * \\
(0.089)\end{array}$ & $\begin{array}{c}1.224 * * * \\
(0.101)\end{array}$ \\
\hline Managerial & $\begin{array}{c}1.252 * * * \\
(0.047)\end{array}$ & $\begin{array}{c}0.998 * * * \\
(0.073)\end{array}$ & $\begin{array}{c}0.842 * * * \\
(0.091)\end{array}$ \\
\hline Skilled, non-manual & $\begin{array}{c}0.881 * * * \\
(0.049)\end{array}$ & $\begin{array}{c}0.676^{* * *} \\
(0.076)\end{array}$ & $\begin{array}{c}0.589 * * * \\
(0.095)\end{array}$ \\
\hline Skilled, manual & $\begin{array}{c}0.561 * * * \\
(0.040)\end{array}$ & $\begin{array}{c}0.457 * * * \\
(0.066)\end{array}$ & $\begin{array}{c}0.248 * * * \\
(0.091)\end{array}$ \\
\hline Semi-skilled & $\begin{array}{c}0.304 * * * \\
(0.048)\end{array}$ & $\begin{array}{c}0.220 * * * \\
(0.079)\end{array}$ & $\begin{array}{c}0.243 * * \\
(0.105)\end{array}$ \\
\hline $\begin{array}{l}\text { Chi-square test ( } p \text {-value) } \\
\text { Significance of father classes }\end{array}$ & $\begin{array}{l}1366.90 \\
(0.0000)\end{array}$ & $\begin{array}{c}443.58 \\
(0.0000)\end{array}$ & $\begin{array}{c}439.48 \\
(0.0000)\end{array}$ \\
\hline $\begin{array}{l}\text { Chi-square test ( } p \text {-value), } \\
\text { equality of coefficients }\end{array}$ & & $\begin{array}{l}46.66 \\
(0.0000\end{array}$ & \\
\hline Number obs & 10217 & 4450 & 4370 \\
\hline
\end{tabular}

Notes. Ordered probit regression coefficients reported, with standard errors presented in parentheses. All regressions include indicators for ethnicity and sex. Whitehall II regressions also include controls for age and age squared at phase 1. The NCDS asked about the highest qualification a cohort member had obtained by age 23. The Whitehall II asked about the level of qualification when the individual first left full-time education. In all regressions, the benchmark for father's social class is unskilled. The chi-square test for equality of coefficients tests the null hypothesis that the coefficients on the father's class indicators are equal across columns 1 and 2. 
Table 4. Tests of equality between restricted BCS, NCDS and Whitehall II coefficients

\begin{tabular}{|c|c|c|c|c|c|c|c|c|}
\hline & \multicolumn{3}{|c|}{ Height in centimeters } & \multicolumn{3}{|c|}{$\begin{array}{l}\text { Self-assessed health Excellent or } \\
\text { Excellent/Very Good }\end{array}$} & \multicolumn{2}{|c|}{ Educational Qualification } \\
\hline & $\begin{array}{l}\text { BCS } \\
\text { (all) }\end{array}$ & $\begin{array}{l}\text { NCDS } \\
\text { (all) }\end{array}$ & $\begin{array}{c}\text { W II } \\
\text { (3civil service } \\
\text { grades) }\end{array}$ & $\begin{array}{l}\text { BCS } \\
\text { (all) }\end{array}$ & $\begin{array}{l}\text { NCDS } \\
\text { (all) }\end{array}$ & $\begin{array}{c}\text { W II } \\
\text { (3civil service } \\
\text { grades) }\end{array}$ & $\begin{array}{l}\text { NCDS } \\
\text { (all) }\end{array}$ & $\begin{array}{c}\text { W II } \\
\text { (3civil service } \\
\text { grades) }\end{array}$ \\
\hline Father's social class & $\begin{array}{l}0.596 * * * \\
(0.065)\end{array}$ & $\begin{array}{l}0.614^{* * *} \\
(0.057)\end{array}$ & $\begin{array}{l}0.363 * * * \\
(0.060)\end{array}$ & $\begin{array}{l}0.032 * * * \\
(0.004)\end{array}$ & $\begin{array}{l}0.037 * * * \\
(0.004)\end{array}$ & $\begin{array}{l}0.017 * * * \\
(0.004)\end{array}$ & $\begin{array}{c}0.324 * * * \\
(0.009)\end{array}$ & $\begin{array}{l}0.261 * * * \\
(0.013)\end{array}$ \\
\hline Number obs & 7347 & 9256 & 6919 & 7370 & 9362 & 20528 & 10217 & 4370 \\
\hline $\begin{array}{l}\text { Test: coefficient BCS, } \\
\text { NCDS = coeff WII ( } p \text {-val) }\end{array}$ & $\begin{array}{c}2.66 \\
(0.008)\end{array}$ & $\begin{array}{c}3.03 \\
(0.003)\end{array}$ & -- & $\begin{array}{c}2.65 \\
(0.008) \\
\end{array}$ & $\begin{array}{c}3.54 \\
(0.000) \\
\end{array}$ & -- & $\begin{array}{c}3.98 \\
(0.000) \\
\end{array}$ & -- \\
\hline & $\begin{array}{c}\text { BCS } \\
\text { (top } 3 \\
\text { classes) }\end{array}$ & $\begin{array}{l}\text { NCDS } \\
\text { (top } 3 \\
\text { classes) }\end{array}$ & $\begin{array}{c}\text { W II } \\
\text { (3civil service } \\
\text { grades) }\end{array}$ & $\begin{array}{c}\text { BCS } \\
\text { (top } 3 \\
\text { classes) }\end{array}$ & $\begin{array}{l}\text { NCDS } \\
\text { (top } 3 \\
\text { classes) }\end{array}$ & $\begin{array}{c}\text { W II } \\
\text { (3civil service } \\
\text { grades) }\end{array}$ & $\begin{array}{l}\text { NCDS } \\
\text { (top } 3 \\
\text { classes) }\end{array}$ & $\begin{array}{c}\text { W II } \\
\text { (3civil service } \\
\text { grades) }\end{array}$ \\
\hline Father's social class & $\begin{array}{l}0.510 * * * \\
(0.084)\end{array}$ & $\begin{array}{l}0.531 * * * \\
(0.077)\end{array}$ & $\begin{array}{l}0.363 * * * \\
(0.060)\end{array}$ & $\begin{array}{l}0.022 * * * \\
(0.006)\end{array}$ & $\begin{array}{l}0.026^{* * *} \\
(0.005)\end{array}$ & $\begin{array}{l}0.017 * * * \\
(0.004)\end{array}$ & $\begin{array}{l}0.266^{* * *} \\
(0.013)\end{array}$ & $\begin{array}{l}0.261 * * * \\
(0.013)\end{array}$ \\
\hline Number obs & 4040 & 4528 & 6919 & 4048 & 5125 & 20258 & 4450 & 4370 \\
\hline $\begin{array}{l}\text { Test: coefficient BCS, } \\
\text { NCDS = coeff WII ( } p \text {-val) }\end{array}$ & $\begin{array}{c}1.42 \\
(0.155)\end{array}$ & $\begin{array}{c}1.72 \\
(0.086)\end{array}$ & -- & $\begin{array}{c}0.69 \\
(0.487)\end{array}$ & $\begin{array}{c}1.41 \\
(0.159)\end{array}$ & -- & $\begin{array}{c}0.27 \\
(0.789)\end{array}$ & -- \\
\hline
\end{tabular}

Notes. Height regressions and self-assessed health status regressions present OLS coefficients, with standard errors in parentheses. Educational attainment regressions present ordererd probit coefficients with standard errors in parenthesis. In all regressions, father's social class is entered linearly ( $6=$ professional; $5=$ managerial; $4=$ skilled, non-manual; $3=$ skilled, manual; $2=$ semi-skilled; $1=$ unskilled). Self-assessed health is reported at age 30 in the BCS, age 42 in the NCDS, and is reported between phases 3 and 6 for the Whitehall II data. Whitehall II health is an indicator of "Excellent or very good health" on a five-point scale. NCDS and BCS health is an indicator of "Excellent" health on a 4-point scale. All regressions include indicators for ethnicity and sex. Whitehall II regressions also include controls for age and age squared. Whitehall II regressions for self-assessed health also include indicators for the phase in which the response was given, and cluster the standard errors by individual. 


\begin{tabular}{|c|c|c|c|c|}
\hline \multirow[b]{3}{*}{$\begin{array}{l}\text { Satisfied with health } \\
\text { at phase } 1\end{array}$} & \multicolumn{4}{|c|}{ Dependent variable: } \\
\hline & \multicolumn{2}{|c|}{$\begin{array}{l}\text { Entry Promotion } \\
\text { without controls for } \\
\text { education }\end{array}$} & \multicolumn{2}{|c|}{$\begin{array}{l}\text { Entry Promotion } \\
\text { with controls for } \\
\text { education }\end{array}$} \\
\hline & -- & $\begin{array}{l}0.036^{* *} \\
(0.015)\end{array}$ & -- & $\begin{array}{l}0.032 * * \\
(0.014)\end{array}$ \\
\hline Height $(\mathrm{cm})$ & $\begin{array}{l}0.005 * * * \\
(0.001)\end{array}$ & $\begin{array}{l}0.005 * * * \\
(0.001)\end{array}$ & $\begin{array}{l}0.004 * * * \\
(0.001)\end{array}$ & $\begin{array}{l}0.005 * * * \\
(0.001)\end{array}$ \\
\hline \multicolumn{5}{|l|}{ Father's occupational class: } \\
\hline Professional & $\begin{array}{l}0.425 * * * \\
(0.054)\end{array}$ & $\begin{array}{l}0.179 * * * \\
(0.046)\end{array}$ & $\begin{array}{l}0.141^{* * * *} \\
(0.046)\end{array}$ & $\begin{array}{l}0.080^{*} \\
(0.044)\end{array}$ \\
\hline Managerial & $\begin{array}{l}0.276 * * * \\
(0.048)\end{array}$ & $\begin{array}{c}0.133 * * * \\
(0.041)\end{array}$ & $\begin{array}{l}0.074 * \\
(0.041)\end{array}$ & $\begin{array}{c}0.057 \\
(0.039)\end{array}$ \\
\hline Skilled, non-manual & $\begin{array}{l}0.164 * * * \\
(0.050)\end{array}$ & $\begin{array}{l}0.128 * * * \\
(0.042)\end{array}$ & $\begin{array}{c}0.032 \\
(0.043)\end{array}$ & $\begin{array}{c}0.065 \\
(0.040)\end{array}$ \\
\hline Skilled, manual & $\begin{array}{l}0.131 * * * \\
(0.047)\end{array}$ & $\begin{array}{l}0.067^{*} \\
(0.040)\end{array}$ & $\begin{array}{c}0.059 \\
(0.040)\end{array}$ & $\begin{array}{c}0.047 \\
(0.038)\end{array}$ \\
\hline Semi-skilled & $\begin{array}{c}0.074 \\
(0.054)\end{array}$ & $\begin{array}{l}0.085^{*} \\
(0.046)\end{array}$ & $\begin{array}{c}0.007 \\
(0.046)\end{array}$ & $\begin{array}{c}0.045 \\
(0.044)\end{array}$ \\
\hline $\begin{array}{l}\text { Family owned a car when }<16 \\
\text { years old }\end{array}$ & $\begin{array}{c}0.088^{* * * *} \\
(0.019)\end{array}$ & $\begin{array}{c}0.001 \\
(0.016)\end{array}$ & $\begin{array}{c}0.052 * * * \\
(0.016)\end{array}$ & $\begin{array}{l}-0.005 \\
(0.015)\end{array}$ \\
\hline $\begin{array}{l}\text { Member spent } 4+\text { weeks in } \\
\text { hospital when }<16 \text { years old }\end{array}$ & $\begin{array}{c}-0.063 * * \\
(0.026)\end{array}$ & $\begin{array}{c}-0.047 * * \\
(0.022)\end{array}$ & $\begin{array}{l}-0.029 \\
(0.022)\end{array}$ & $\begin{array}{c}-0.037 * \\
(0.021)\end{array}$ \\
\hline $\begin{array}{l}F \text {-test Father's class variables ( } p \text { - } \\
\text { value) }\end{array}$ & $\begin{array}{c}27.38 \\
(0.000)\end{array}$ & $\begin{array}{c}5.95 \\
(0.000)\end{array}$ & $\begin{array}{c}3.98 \\
(0.001)\end{array}$ & $\begin{array}{c}0.80 \\
(0.550)\end{array}$ \\
\hline $\begin{array}{l}F \text {-test Family background } \\
\text { variables ( } p \text {-value) }\end{array}$ & $\begin{array}{c}14.59 \\
(0.000)\end{array}$ & $\begin{array}{c}2.37 \\
(0.094)\end{array}$ & $\begin{array}{c}6.45 \\
(0.002)\end{array}$ & $\begin{array}{c}1.65 \\
(0.192)\end{array}$ \\
\hline $\begin{array}{l}F \text {-test Educational qualification } \\
\text { vars ( } p \text {-value) }\end{array}$ & -- & -- & $\begin{array}{l}150.73 \\
(0.000)\end{array}$ & $\begin{array}{c}37.91 \\
(0.000)\end{array}$ \\
\hline Number of observations & 3914 & 3746 & 3914 & 3746 \\
\hline
\end{tabular}

Notes. OLS regression coefficients are presented, with standard errors in parentheses. A complete set of educational qualification indicators are included in columns 3 and 4. All regressions include indicators for ethnicity, sex, age and age squared at phase 1. Regressions for promotion also include an indicator for first grade at Whitehall. The sample for promotion is restricted to cohort members who enter in a grade lower than "administrative," the highest grade. 


\begin{tabular}{|c|c|c|c|c|}
\hline \multirow[b]{2}{*}{ First grade at Whitehall } & \multicolumn{4}{|c|}{$\begin{array}{c}\text { Dependent variable: Self-reported health status } \\
\text { (5=Excellent, } 4=\text { =Very Good, 3=Good, } 2=\text { Fair, } 1=\text { Poor) }\end{array}$} \\
\hline & $\begin{array}{c}0.104 * * * \\
(0.034)\end{array}$ & $\begin{array}{c}0.024 \\
(0.041)\end{array}$ & $\begin{array}{l}-0.021 \\
(0.053)\end{array}$ & $\begin{array}{c}0.016 \\
(0.064)\end{array}$ \\
\hline Current grade at Whitehall & -- & $\begin{array}{c}0.125 * * * \\
(0.032)\end{array}$ & $\begin{array}{l}-0.005 \\
(0.058)\end{array}$ & $\begin{array}{l}-0.006 \\
(0.075)\end{array}$ \\
\hline $\begin{array}{l}\text { Grade at next phase } \\
\text { [current phase }+1]\end{array}$ & -- & -- & $\begin{array}{c}0.141 * * * \\
(0.055)\end{array}$ & -- \\
\hline Grade at [current phase +2 ] & -- & -- & -- & $\begin{array}{c}0.136^{* * * *} \\
(0.070)\end{array}$ \\
\hline Height (cm) & $\begin{array}{c}0.004 \\
(0.002)\end{array}$ & $\begin{array}{l}0.005^{*} \\
(0.003)\end{array}$ & $\begin{array}{l}0.006^{*} \\
(0.003)\end{array}$ & $\begin{array}{c}0.004 \\
(0.004)\end{array}$ \\
\hline $\begin{array}{l}\text { Member spent } 4+\text { weeks in } \\
\text { hospital when }<16 \text { years old }\end{array}$ & $\begin{array}{l}-0.202 * * * \\
(0.046)\end{array}$ & $\begin{array}{l}-0.205 * * * \\
(0.055)\end{array}$ & $\begin{array}{l}-0.195 * * * \\
(0.068)\end{array}$ & $\begin{array}{c}-0.228 * * * \\
(0.079)\end{array}$ \\
\hline $\begin{array}{l}\text { Mother gave 'a great deal of } \\
\text { time' while growing up }\end{array}$ & $\begin{array}{c}0.209^{* * *} \\
(0.031)\end{array}$ & $\begin{array}{c}0.187 * * * \\
(0.036)\end{array}$ & $\begin{array}{c}0.176^{* * * *} \\
(0.044)\end{array}$ & $\begin{array}{c}0.185^{* * *} \\
(0.051)\end{array}$ \\
\hline $\begin{array}{l}\text { Chi-square test: Education } \\
\text { qualification (p-value) }\end{array}$ & $\begin{array}{l}28.96 \\
(0.001)\end{array}$ & $\begin{array}{l}18.86 \\
(0.042)\end{array}$ & $\begin{array}{c}17.32 \\
(0.068)\end{array}$ & $\begin{array}{c}21.07 \\
(0.021)\end{array}$ \\
\hline $\begin{array}{l}\text { Chi-square test: family had a car, } \\
\text { member hospitalized }\end{array}$ & $\begin{array}{c}24.35 \\
(0.000)\end{array}$ & $\begin{array}{l}17.65 \\
(0.000)\end{array}$ & $\begin{array}{l}10.26 \\
(0.006)\end{array}$ & $\begin{array}{c}8.83 \\
(0.012)\end{array}$ \\
\hline $\begin{array}{l}\text { Chi-square test: Mother gave } \\
\text { time, mother's education }\end{array}$ & $\begin{array}{c}51.73 \\
(0.000)\end{array}$ & $\begin{array}{c}32.14 \\
(0.000)\end{array}$ & $\begin{array}{c}20.91 \\
(0.000)\end{array}$ & $\begin{array}{c}20.14 \\
(0.000)\end{array}$ \\
\hline Chi-square test: Parents' illness & $\begin{array}{l}27.78 \\
(0.000)\end{array}$ & $\begin{array}{c}27.89 \\
(0.000)\end{array}$ & $\begin{array}{c}16.10 \\
(0.003)\end{array}$ & $\begin{array}{c}12.26 \\
(0.016)\end{array}$ \\
\hline Number obs & 13557 & 8664 & 5199 & 2902 \\
\hline
\end{tabular}

Notes. Ordered probit regression coefficients are presented, with standard errors in parentheses. Standard errors are clustered at the individual level. All regressions include controls for ethnicity, sex, age and age squared; a complete set of educational qualification indicators; members' reports that their family had a car when less than 16; mother's school-leaving age and school-leaving age squared; and indicators for members' reports that either parent had had high blood pressure, diabetes, angina and stroke. Civil service grades are recorded: $1=$ clerical or office support; $2=$ professional or executive; $3=$ administrative. 
Table 7. Fixed effect models of occupational grade and health

\begin{tabular}{|c|c|c|c|c|c|c|}
\hline \multirow[b]{3}{*}{ Estimation technique: } & \multicolumn{6}{|c|}{ Dependent variable: } \\
\hline & \multicolumn{3}{|c|}{ Indicator: Health is excellent or very good } & \multicolumn{3}{|c|}{ Current civil service grade } \\
\hline & $\begin{array}{l}\text { Fixed } \\
\text { effects }\end{array}$ & $\begin{array}{l}\text { Fixed } \\
\text { Effects }\end{array}$ & $\begin{array}{c}\text { First } \\
\text { differences }\end{array}$ & $\begin{array}{l}\text { Fixed } \\
\text { effects }\end{array}$ & $\begin{array}{l}\text { Fixed } \\
\text { effects }\end{array}$ & $\begin{array}{c}\text { First } \\
\text { differences }\end{array}$ \\
\hline Explanatory variables: & & & & & & \\
\hline Civil service grade $(t-1)$ & $\begin{array}{c}0.019 \\
(0.017)\end{array}$ & -- & -- & -- & -- & -- \\
\hline Civil service grade $(t-2)$ & $\begin{array}{c}0.004 \\
(0.015)\end{array}$ & $\begin{array}{c}0.002 \\
(0.013)\end{array}$ & -- & -- & -- & -- \\
\hline $\begin{array}{l}\text { Change in civil service grade } \\
(t-2)-(t-3)\end{array}$ & -- & -- & $\begin{array}{c}0.004 \\
(0.015)\end{array}$ & -- & -- & -- \\
\hline Health excellent/very good $(t-1)$ & -- & -- & -- & $\begin{array}{c}0.030 \\
(0.019)\end{array}$ & -- & -- \\
\hline Health excellent/very good $(t-2)$ & -- & -- & -- & $\begin{array}{c}0.037 * * \\
(0.018)\end{array}$ & $\begin{array}{l}0.028^{*} \\
(0.016)\end{array}$ & -- \\
\hline $\begin{array}{l}\text { Change in health } \\
(t-2)-(t-3)\end{array}$ & -- & -- & -- & -- & -- & $\begin{array}{l}0.028^{*} \\
(0.016)\end{array}$ \\
\hline Age & $\begin{array}{l}-0.001 \\
(0.001)\end{array}$ & $\begin{array}{l}-0.001 \\
(0.001)\end{array}$ & $\begin{array}{l}-0.006 \\
(0.005)\end{array}$ & $\begin{array}{l}-0.017 * * * \\
(0.003)\end{array}$ & $\begin{array}{l}-0.017 * * * \\
(0.002)\end{array}$ & $\begin{array}{l}-0.013 \\
(0.017)\end{array}$ \\
\hline Number of observations & 22,071 & 26,233 & 17,069 & 5322 & 5688 & 2151 \\
\hline
\end{tabular}


Appendix Table 1.

Data used in our analysis from Whitehall II

\begin{tabular}{|c|c|c|c|c|c|c|}
\hline & Phase 1 & Phase 2 & Phase 3 & Phase 4 & Phase 5 & Phase 6 \\
\hline Collection Dates: & $1985-88$ & $1989-90$ & 1991-94 & 1995-96 & 1997-99 & 2001 \\
\hline Age & $\mathrm{X}$ & $\mathrm{X}$ & $\mathrm{X}$ & $\mathrm{X}$ & $\mathrm{X}$ & $\mathrm{X}$ \\
\hline Sex & $\mathrm{X}$ & $\mathrm{X}$ & $\mathrm{X}$ & & & \\
\hline Ethnicity & & & & & $\mathrm{X}$ & \\
\hline Father's social class & $\mathrm{X}$ & & & & & \\
\hline Mother's school-leaving age & $\mathrm{X}$ & & & & & \\
\hline Family owned a car $<$ age 16 & & & & & $\mathrm{X}$ & \\
\hline $\begin{array}{l}\text { Spent } 4+\text { weeks in hospital } \\
\text { < age } 16\end{array}$ & & & & & $\mathrm{X}$ & \\
\hline Parent suffered from diabetes & $\mathrm{X}$ & & & & & \\
\hline $\begin{array}{l}\text { Parent suffered high blood } \\
\text { pressure }\end{array}$ & $\mathrm{X}$ & & & & & \\
\hline Paren suffered angina & $\mathrm{X}$ & & & & & \\
\hline Parent suffered stroke & $\mathrm{X}$ & & & & & \\
\hline $\begin{array}{l}\text { Mother gave 'a great deal of } \\
\text { time' when needed growing up }\end{array}$ & & & & & $\mathrm{X}$ & \\
\hline Height in adulthood (mean) & $\mathrm{X}$ & & $\mathrm{X}$ & & $\mathrm{X}$ & \\
\hline $\begin{array}{l}\text { Academic qualification when } \\
\text { first left full-time education }\end{array}$ & & & & & $\mathrm{X}$ & \\
\hline Health satisfaction at phase 1 & $\mathrm{X}$ & & & & & \\
\hline First civil service grade & $\mathrm{X}$ & & & & & \\
\hline Current civil service grade & $\mathrm{X}$ & $\mathrm{X}$ & $\mathrm{X}$ & $\mathrm{X}$ & $\mathrm{X}$ & $\mathrm{X}$ \\
\hline Self-assessed health status & & & $\mathrm{X}$ & $\mathrm{X}$ & $\mathrm{X}$ & $\mathrm{X}$ \\
\hline
\end{tabular}

